\title{
SOILS CHARACTERIZATION AND CLASSIFICATION IN CLEAN FIELD, DIRTY FIELD AND FOREST AREAS IN AMAZONIAN ENVIRONMENTS
}

\author{
CARACTERIZAÇÃO E CLASSIFICAÇÃO DE SOLOS EM ÁREA DE CAMPO LIMPO, \\ CAMPO SUJO E FLORESTA EM AMBIENTES AMAZÔNICOS
}

\author{
Uilson FRANCISCON ${ }^{1}$; Milton César Costa CAMPOS $^{\mathbf{1}}$; \\ Bruno Campos MANTOVANELLI ${ }^{2}$; Luís Antônio Coutrim dos SANTOS ${ }^{2}$; \\ José Maurício da CUNHA ${ }^{1}$; Leonardo CHECHI ${ }^{3}$ Ivanildo Amorim de OLIVEIRA ${ }^{4}$ \\ 1. Colegiado de Engenharia Ambiental, Universidade Federal do Amazonas, Instituto de Educação Agricultura e Ambiente-IEAA, \\ Humaitá, AM, Brasil; 2. Departamento de Ciência do Solo, Universidade Federal de Santa Maria, Santa Maria, Rio Grande do Sul, \\ Brasil. brunomantovanelli21@gmail.com; 3. Departamento de Engenharia Rural, Universidade Federal de Santa Maria, Santa Maria, \\ RS, Brasil; 4. Campus Ariquemes, Instituto Federal de Educação, Ciência e Tecnologia de Rondônia, Ariquemes, RO, Brasil
}

\begin{abstract}
The soil and vegetation characteristics of the southern Amazonas region include highly weathered soils, high aluminum content and some hydromorphic conditions, its vegetation is composed from grasslands to small isolated trees and forest galleries along the rivers streams. In this way, this work aims to characterize and classify the soil in areas of clean field, dirty field, and forest in Humaitá region AM. Soil trenches were opened in the clean field, dirty field, and forest environments, soil profiles were morphologically characterized, and samples were collected from their horizons. Physical analysis of texture, dispersed clay in water, flocculation, bulk density, particle density and porosity were performed. The chemical analyzes included $\mathrm{pH}$ and $\mathrm{KCl}$ in water; $\mathrm{Ca}, \mathrm{Mg}, \mathrm{K}, \mathrm{Al}$, and; available $\mathrm{P} ; \mathrm{H}+\mathrm{Al}$ and organic $\mathrm{C} ; \mathrm{SiO}_{2}, \mathrm{Al}_{2} \mathrm{O}_{3}$ and $\mathrm{Fe}_{2} \mathrm{O}_{3}$ sulfuric attack. The soils were classified according to criteria established by the Brazilian System of Soil Classification and Soil Taxonomy. The forest, dirty field (high) and clean field (low) showed different soil types, Typic Dystrudept for the first two environments and Typic Fluvaquents for last. Multivariate techniques expressed the similarity relations presenting between the different environments studied, characterizing, which are of great importance in the relation landscape-soil studies.
\end{abstract}

KEYWORDS: Amazon soil. Soil genesis. Soil attributes. Soil classification.

\section{INTRODUCTION}

The landscape is the combination of the earth surface features and the subsurface components (source material) (PENNOCK; VELDKAMP, 2006), while soil is a natural threedimensional and dynamic body that is inserted in the landscape (MINASNY; MCBRATNEY, 2006). In this way, the relation "soil-landscape" can be understood as the soil attributes spatial pattern distribution and its dependence relations with the landform arrangement (CAMPOS et al., 2007). However, climatic conditions, geological characteristics and hydrological aspects are fundamental to understand these relationships (CAMPOS et al., 2013a).

The Amazonas region presents a great soil diversity and landscapes, which justifies studies of this nature, among these landscapes, the Humaitá city presents transition vegetation of the Field/Forest type, which includes the so-called "Humaitá Natural Fields", that comprise the areas of the "PuciariHumaitá fields". This landscape type includes several open country formations, alternating small isolated trees and forest galleries along the streams known as "igarapés" (BRAUN; RAMOS, 1959).

These fields form some mosaics with the surrounding forests, the contact between these vegetations occurs in some places, abruptly, but in others the vegetation changes between the forest and the field is gradual (FREITAS et al., 2002). Braun \& Ramos (1959) add that vegetative associations occur, forming the: "clean field" areas which are not very extensive and with grasses predominance; the "dirty field" areas are dominated and covered by grasses associated with shrubs and trees and finally in the areas near the fields edges occur woods, with trees spacing between 1 and $3 \mathrm{~m}$, reaching 3 to $5 \mathrm{~m}$ height.

The native Amazonian fields origin in a certain way presents several theories, but supposedly different from those presented to explain the Central Brazil "Cerrados" occurrence. According to the forest refuges theory, during the Pleistocene, that goes from 2 million to 12 thousand years ago, occurred several glaciations responsible for the planet cooling, in the Amazônia the average temperature fell at least $4.5{ }^{\circ} \mathrm{C}$ and in the dry 
periods, the area was dominated by savannas and "Cerrados", the forest was reduced to tropical vegetation small "spots" called refuges (RANZI, 1993, MARTINS et al., 2006).

The relationships between soil, landform and vegetation are characterized to be interdependent, if drainage conditions and soil variation interfere with plant formations, on the other hand, landform conditions influence soil properties such as structure, porosity, bulk density and nutrient content (MEIRELES et al., 2012). Studies conducted by Campos et al. (2012) in field/forest transition environments, found that in these environments the soil variation in toposequence is directly related to the landform, which drives the drainage and water table level, favoring the glei or plintico horizons appearance in "Sistema Brasileiro de Classificação de Solos (SIBCS)".

So, the soil study presents a great importance for humanity, being used in several activities, including agricultural and environmental, given the above, the morphological characteristics, physical and chemical attributes study is of the utmost importance for inferences to be made about to the potential use, as well as in the soil-landscape relationship processes. On the other hand, the natural fields present a unique occurrence in the Amazonas southern region, which gives them exclusive characteristics, considering the fact that the region is inserted in the so-called "deforestation arc", with the possibility to lose these environments. In this way, the present study aimed to characterize and classify the soils in dirty field, clean field and forest environments in the Humaitá - AM region.

\section{MATERIAL AND METHODS}

\section{Physical environmental characterization}

The study area is located in the Amazonas southern region in the Humaitá city, AM (Figure 1). The region climate, according to the Köppen classification, belongs to group A (Tropical Rainy Weather) and climatic type Am (monsoon type rainfall), presenting a dry period of short duration. Rainfall is limited by 2,250 and 2,750 $\mathrm{mm}$ isohyets with a rainy period beginning in October and going through June. Average annual temperatures range from $25{ }^{\circ} \mathrm{C}$ to $27{ }^{\circ} \mathrm{C}$ and air relative humidity is between 85 and $90 \%$.
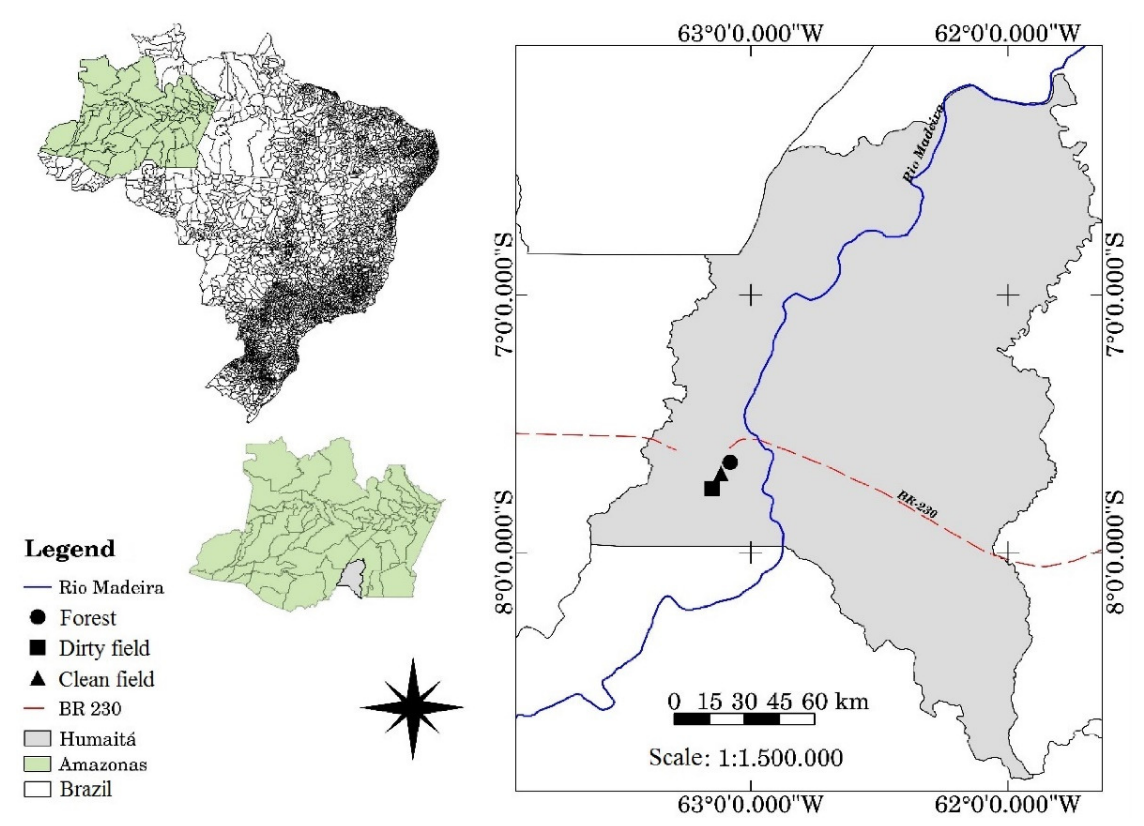

Figure 1. Location map of clean field, dirty field and forest areas in the Humaitá region, Amazonas.

The studied area geology is formed by undifferentiated ancient alluvium referred to the Holocene, this formation sediments are derived from two sedimentation cycles: a) lower, sandy banks that represent pluvial-fluvial sedimentation and b) higher clayey sediments, indicating lacustrine sedimentation (BRAUN; RAMOS, 1959). The region presents approximately "plateau" type landform, with very small differences and slightly bulging edges. These ancient river terraces are water divisors between the region small streams. These tabular zones unevenness in relation to the streams are in the order of 15 to $29 \mathrm{~m}$, however, occurs abruptly (BRAUN; RAMOS, 1959). 
Generally, the two vegetation types in the region are forests and natural fields, the forests are the tropical rainforest-type open and dense, and the Puciari-Humaitá fields are where clean and dirty fields stand, with formations prevailing low grassywoody vegetation, which sometimes alternate small isolated trees and forest galleries along the rivers and the undergrowth consists mainly of grasses and is distributed as clusters spaced from 0.40 to $0.60 \mathrm{~m}$ from each other (BRAUN; RAMOS, 1959).

\section{Field and laboratory methodology}

Soil trenches were opened in clean field (P1), dirty field (P2) and forest (P3) environments, to characterize morphological features, and to collect soil samples for physical and chemical analysis. The soil profiles were described morphologically by horizons following Santos et al. (2013) recommendations. Soils were classified according to criteria established by the Brazilian Soil Classification System (Embrapa, 2013) and Soil Taxonomy (Soil Survey Staff, 2014).

The granulometric analysis was performed by the pipette method, using $0.1 \mathrm{NaOH} \mathrm{mol} \mathrm{L}^{-1}$ solution as a chemical dispersant and mechanical stirring in low speed apparatus for $16 \mathrm{~h}$ using a soil dispersion mixer Wagner type. The clay fraction was separated by sedimentation, the coarse and fine sand by sieving and silt calculated by difference (Embrapa, 2011). The fractions larger than $2 \mathrm{~mm}$ (gravel 2-20 $\mathrm{mm}$ ) present in the soil samples were quantified by weighing, and calculating the gravel mass by sample mass ratio.

Undisturbed structure samples were collected in each of the profile horizons, using a soil core sampler and in the laboratory the samples were prepared by removing the soil excess from its ends, then saturated by water surface gradual elevation by about $2 / 3$ of samples height in an aluminum container. The total porosity was obtained by the saturation method, in which the relationship between the saturation moisture and the respective soil volume represents the total porosity. Soil density was determined from samples with preserved structure, obtained by the ratio between oven dried soil at $105^{\circ} \mathrm{C}$ mass and the soil volume as described in Embrapa (2011) and the particle density determined by the volumetric flask method, according to methodology described by Flint \& Flint (2002).

Potassium and phosphorus were extracted with Mehlich ${ }^{-1}$ solution; and the potential acidity $(\mathrm{H}+\mathrm{Al})$ extracted with calcium acetate buffered solution at $\mathrm{pH} 7.0$, using a methodology proposed by Embrapa (2011). Based on chemical analyzes results, the sum of bases (SB), cation exchange capacity (CEC), base saturation (V\%) and aluminum saturation $(\mathrm{m})$ were calculated. The $\mathrm{pH}$ was determined potentiometrically using a 1:2.5 soil ratio: in water and $1 \mathrm{~mol} \mathrm{~L}^{-1} \mathrm{KCl}$ solution (Embrapa, 2011). The total organic carbon was determined by the humid oxidation method, with external heating (YEOMANS; BREMNER, 1988).

In the air-dried soil samples were determined the sulfuric oxides attack $\left(\mathrm{Al}_{2} \mathrm{O}_{3}\right.$ and $\mathrm{Fe}_{2} \mathrm{O}_{3}$ ) after digestion with $\mathrm{H}_{2} \mathrm{SO}_{4}, 1: 1$ ratio, followed by alkaline dissolution of $\mathrm{SiO}_{2}$ following the method described by Embrapa (1979).

The data were submitted to Principal Component Analysis (PCA), aiming to summarize the values obtained from the attributes studied. In this way, the 13 initial variables set was characterized by two new latent variables (PC1 and PC2), which allowed its location in two-dimensional figures (access order by PCA). The analysis accuracy is verified by the original variables total information, retained in the principal components that show eigenvalues higher than the unit, or lower eigenvalues without relevant information. All multivariate statistical analyzes were processed in STATISTICA software version 7.0 (Statsoft, 2004).

\section{RESULTS AND DISCUSSION}

\section{Genesis and soil classification}

The soil profiles variation along the different physiographic environments is closely related to the landform that drives drainage and surface runoff, framing these environments in different soil classes. As for the profiles genesis and classification, all presented horizon diagnosis superficial Ocrich Epipedon.

Regarding the soil taxonomy it was observed the formation of two classes according to the SiBCS: the first in the Entisols order (P1), the second and the third in the Inceptisols order (P2 and $\mathrm{P} 3)$. The P1 was classified as Aquents, located in the flat area of the studied environment, and favored by hydromorphic conditions, leading to the massive structure formation and grayish colors in the $\mathrm{Cg}$ horizon, expressing the gleying process predominance. Due to the high aluminum saturation index, greater than $50 \%$ and base saturation, less than $50 \%$ throughout the profile, this was classified as Typic Fluvaquents.

$\mathrm{P} 2$ and $\mathrm{P} 3$ presented incipient subsurface $\mathrm{B}$ horizons diagnostic, without evidence of predominant pedogenetic process, also presenting allytic character for both soils, being classified as Typic Dystrudept. 
Allytic character found in the studied environments is due to high exchangeable aluminum contents $\left(\geq 4 \mathrm{cmol}_{\mathrm{c}} \mathrm{kg}^{-1}\right.$, associated to clay activity $\left.\geq 20 \mathrm{cmol}_{\mathrm{c}} \mathrm{kg}^{-1}\right)$. This feature is related to the alluvial parent material, from Madeira River affluent (CAMPOS et al., 2012).

\section{Morphological attributes}

The morphological attributes are presented in (Table 1). P1 presents colors varying from very dark brown (10 YR 2/2) to dark brown (10YR 3/3) in its surface horizons $A$ and $A B$, respectively, thus establishing distinct differentiation for the $\mathrm{Cgf}$ horizons that present colors varying from brown to gray-pink (Figure 2). The darker colors present in the superficial horizons are due to the profile higher organic carbon content, corroborating with Santos et al. (2012), where the authors working with soil characterization in a toposequence under alluvial terraces in the middle Madeira River (AM) region attributed the superficial horizons low values and chroma to the highest levels of organic matter.

Almost all the P1 horizons (Figure 2), exception for A, presented mottles, which varied from little to abundant, medium to large and diffuse to prominent. Their colors ranged from dark brown (7.5 YR 3/4) to dark red (2.5 YR 4/8). This profile is characterized by being seasonally in hydromorphic conditions, being partially flooded at some times of the year. This soil is in the gleying process, according to the observed reduction color patterns evidenced by the mottles formation.

The P2 (Figure 3) presented colors ranging from dark yellowish brown (10 YR 3/4) to strong brown, and in most diagnostic horizons the predominant color was red. Mottles occurrence starts from the $\mathrm{Bif}_{2}$ horizon, alternating colors between yellow (10 YR 7/6) and dark red (2.5 YR 4/6). The mottles formation is due to soil flooding at some times of the year, thus intensifying iron reduction process and transport along the profile (GUIMARÃES et al., 2013).

The P3 (Figure 4) presented yellowish colors in most diagnostic horizons, unlike P2 and $\mathrm{P} 1$, with a color ranging from strong brown (7.5 YR 4/6) to pinkish gray (7.5 YR 7/2). The mottles occurrence starts from the $\mathrm{Bif}_{2}$ horizon, varying in amount, size, color contrast in relation to the bottom, from little to abundant, small to large, diffuse to prominent and dark red in all mottles.

All profiles studied presented a strong degree of development in their structure in all horizons, except for $\mathrm{P} 2 \mathrm{Bif}_{3}$ and P3 Bif3 horizons, which showed a moderate degree of development, with sizes ranging from small, medium and large. The P2 and P3 presented differences in textural classes along the profiles, both surface horizons were characterized as Silty Clay-loam texture, varying for Clay-loam in the subsurface horizons. 
Table 1. Soil morphological attributes in clean field, dirty field and forest areas in the Humaitá region, AM.

\begin{tabular}{|c|c|c|c|c|c|c|c|}
\hline Hor. & Depth. & Collor (Moist) & ${ }^{1}$ Mottles & Texture & ${ }^{2}$ Structure & $\begin{array}{c}{ }^{3} \text { Consistency } \\
\text { (dry, moist and wet) }\end{array}$ & ${ }^{4}$ Transition \\
\hline \multirow{2}{*}{\multicolumn{8}{|c|}{ Profile 1 - Clean Field- Gleissolo Háplico Alítico típico (Typic Fluvaquents) }} \\
\hline & & & & & & & \\
\hline A & $0-22$ & $10 \mathrm{YR} 2 / 2$ & - & Clay-loam & $\begin{array}{l}\text { st. med. ang. bl and } \\
\text { sub. bl }\end{array}$ & sof., fri., sli.pl. sl.sti. & dif. and fla. \\
\hline $\mathrm{AB}$ & $22-40$ & $10 \mathrm{YR} 3 / 3$ & $\begin{array}{l}7.5 \text { YR 3/4 li. } \\
\text { med. dif. }\end{array}$ & Clay-loam & $\begin{array}{l}\text { st. med. to la. ang. bl } \\
\text { and sub. bl }\end{array}$ & sl.har., fri., pl. sti. & dif. and fla. \\
\hline $\mathrm{BA}$ & $40-63$ & $10 \mathrm{YR} 3 / 3$ & $\begin{array}{c}5 \text { YR 3/4 li. med. } \\
\text { dis }\end{array}$ & Clay-loam & $\begin{array}{l}\text { st. med. to la. ang. bl } \\
\text { and sub. bl }\end{array}$ & sl.har., fir., pl. sti. & dif. and fla. \\
\hline $\mathrm{B} / \mathrm{C}$ & $63-88$ & $10 \mathrm{YR} 4 / 4$ & $\begin{array}{l}5 \text { YR } 4 / 6 \text { ab. } \\
\text { med. pro. }\end{array}$ & Clay-loam & $\begin{array}{l}\text { st. med. to la. ang. bl } \\
\text { and sub. bl }\end{array}$ & vha., fir., vpl. vsti. & cle. and fla. \\
\hline Cgf1 & $88-116$ & 7.5 YR 4/4 & $\begin{array}{c}2.5 \text { YR } 4 / 8 \text { ab. la. } \\
\text { pro. }\end{array}$ & Clay-loam & $\begin{array}{l}\text { st. med. to la. ang. bl } \\
\text { and sub.bl }\end{array}$ & ext.ha., fri.,vpl. vsti. & $\begin{array}{l}\text { cle. and } \\
\text { fla. }\end{array}$ \\
\hline Cgf 2 & $116-150$ & 7.5 YR 6/4 & $\begin{array}{l}2.5 \text { YR 4/8 ab. } \\
\text { med. pro. }\end{array}$ & Very clayey & $\begin{array}{l}\text { st. med. to la. ang. bl } \\
\text { and sub. bl }\end{array}$ & ext.ha., fir., vpl. vsti. & dif. and fla. \\
\hline Cgf3 & $150-165+$ & $2.5 \mathrm{Y} 7 / 2$ & $\begin{array}{l}2.5 \text { YR 4/8 ab. } \\
\text { med. pro. }\end{array}$ & Clay & $\begin{array}{l}\text { st. med. to la. ang. bl } \\
\text { and sub. bl }\end{array}$ & ext.ha., fri., vpl. vsti. & - \\
\hline \multicolumn{8}{|c|}{ Profile 2 - Dirty field - Cambissolo Háplico Alítico típico (Typic Dystrudept) } \\
\hline A & $0-11$ & $10 \mathrm{YR} 3 / 4$ & 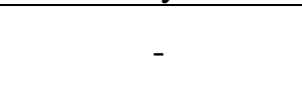 & Silty Clay-loam & $\begin{array}{l}\text { st. med. to la. } \\
\text { ang. bl }\end{array}$ & sof., fri., sli.pl. sl.sti. & $\begin{array}{l}\text { gra. and } \\
\text { fla. }\end{array}$ \\
\hline BA & $11-22$ & 7.5 YR 5/6 & - & Clay-loam & $\begin{array}{l}\text { st. la. to vla. ang. } \\
\text { bl e bl. sub. }\end{array}$ & sof., fri., pl. sti. & dif. and fla. \\
\hline $\mathrm{Bi}$ & $22-40$ & 7.5 YR 6/6 & - & Clay-loam & $\begin{array}{l}\text { st. sm. to med. } \\
\text { ang.bl and sub. bl }\end{array}$ & sl.har., fri., vpl. vsti. & dif. and fla. \\
\hline Bif1 & $40-72$ & $2.5 \mathrm{YR} 5 / 8$ & - & Clay-loam & $\begin{array}{l}\text { st. med. to la. } \\
\text { ang.bl and sub. bl }\end{array}$ & sl.har., fri., vpl. vsti. & cle. and fla. \\
\hline Bif2 & $72-104$ & $2.5 \mathrm{YR} 5 / 8$ & $10 \mathrm{YR} 7 / 6$ & Clay-loam & $\begin{array}{l}\text { st. sm. to med. } \\
\text { ang. bl and sub. bl }\end{array}$ & ha., fri., vpl. vsti. & cle. and fla. \\
\hline Bif3 & $104-125$ & $2.5 \mathrm{YR} 5 / 8$ & 7.5 YR 6/6 & Silty Clay-loam & $\begin{array}{l}\text { mod. sm. to la. } \\
\text { ang. bl and sub. bl }\end{array}$ & vha., fri., vpl. vsti. & dif. and fla. \\
\hline Bif4 & $125-160$ & $7.5 \mathrm{YR} 5 / 8$ & $2.5 \mathrm{YR} 4 / 8$ & Very clayey & $\begin{array}{l}\text { st. med. to la. ang. } \\
\text { bl }\end{array}$ & vha., fri., vpl. vsti. & dif. and fla. \\
\hline $\mathrm{BCf}$ & $160-200$ & 7.5 YR 4/6 & 2.5 YR 4/6 & Very clayey & st. la. to vla. ang. & vha., fri., vpl. vsti. & - \\
\hline
\end{tabular}




\begin{tabular}{|c|c|c|c|c|c|c|c|}
\hline \multicolumn{8}{|c|}{ Profile 3 - Forest - Cambissolo Háplico Alítico típico (Typic Dystrudept) } \\
\hline Af & $0-21$ & $7.5 \mathrm{YR} 4 / 6$ & - & Silty Clay-loam & $\begin{array}{l}\text { st. med. to la. } \\
\text { ang. bl and sub. bl }\end{array}$ & fri., sli.pl. sl.sti & dif. and fla. \\
\hline $\mathrm{ABf}$ & $21-42$ & $2.5 \mathrm{YR} 4 / 6$ & - & Silty Clay-loam & $\begin{array}{l}\text { st. med. to la. ang. } \\
\text { bl and sub. bl }\end{array}$ & fir., pl. sti. & dif. and fla. \\
\hline Bif1 & $42-55$ & $2.5 \mathrm{YR} 4 / 8$ & - & Clay-loam & $\begin{array}{l}\text { st. med.to la. ang. } \\
\text { bl and sub. bl }\end{array}$ & fri., pl. sti. & cle. and fla. \\
\hline Bif2 & $55-80$ & $5 \mathrm{YR} 6 / 6$ & $\begin{array}{c}2.5 \text { YR 3/6 li. sm. } \\
\text { dif. }\end{array}$ & Silty Clay-loam & $\begin{array}{l}\text { st. sm. to med } \\
\text { ang. bl and sub. bl }\end{array}$ & vfri. vpl. vsti. & dif. and fla. \\
\hline Bif3 & $80-106$ & 5 YR 6/8 & $\begin{array}{c}2.5 \text { YR 4/8 ab. la. } \\
\text { pro. }\end{array}$ & Clay-loam & $\begin{array}{l}\text { mod. med. ang. bl } \\
\text { and sub. bl }\end{array}$ & fri. vpl. vsti. & dif. and fla. \\
\hline Bif4 & $106-135$ & 7.5 YR 6/6 & $\begin{array}{c}2.5 \text { YR 4/6 ab. la. } \\
\text { pro. }\end{array}$ & Silty Clay-loam & $\begin{array}{l}\text { st. med. ang. bl } \\
\text { and sub. bl }\end{array}$ & vfir. vpl. vsti. & dif. and fla. \\
\hline Bif5 & $135-155$ & 7.5 YR 6/4 & $\begin{array}{c}2.5 \text { YR 3/6 ab. la. } \\
\text { pro. }\end{array}$ & $\begin{array}{c}\text { Clay-loam } \\
\text { Silty Clay-loam }\end{array}$ & $\begin{array}{l}\text { st. med. ang. bl. } \\
\text { and sub. bl }\end{array}$ & fir. vpl. vsti. & dif. and fla. \\
\hline $\mathrm{BCf}$ & $155-184+$ & 7.5 YR 7/2 & $\begin{array}{c}2.5 \text { YR 4/8 ab. la. } \\
\text { pro. }\end{array}$ & Silty Clay-loam & $\begin{array}{l}\text { st. med. ang.bl. } \\
\text { and sub. bl }\end{array}$ & fir. vpl. vsti. & dif. and fla. \\
\hline
\end{tabular}

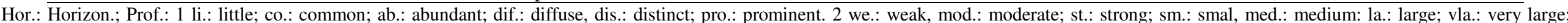

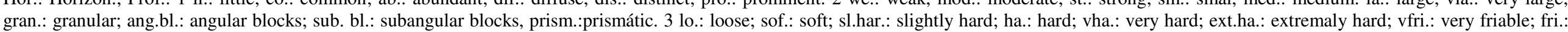

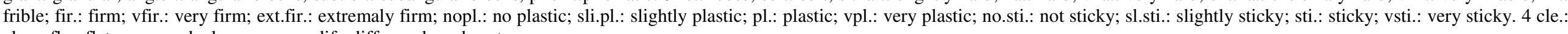
clear; fla.: flat; gra.: gradual; wa.: wavy; dif.: diffuse; abr.: abrupt. 

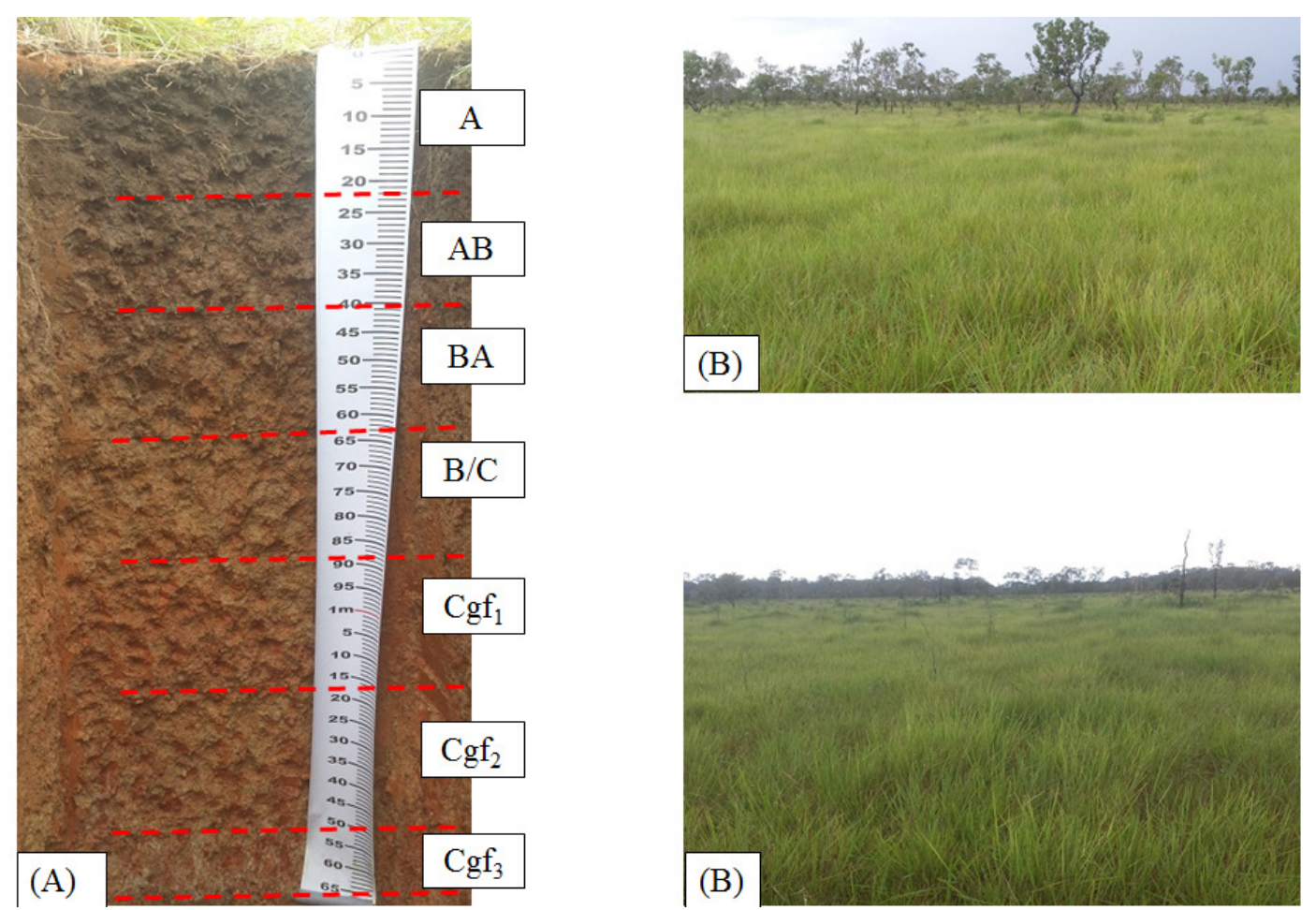

Figure 2. Typic Fluvaquents profile (P1) in clean field area in the Humaitá region, AM. (A) = soil profile and (B) = study environment.
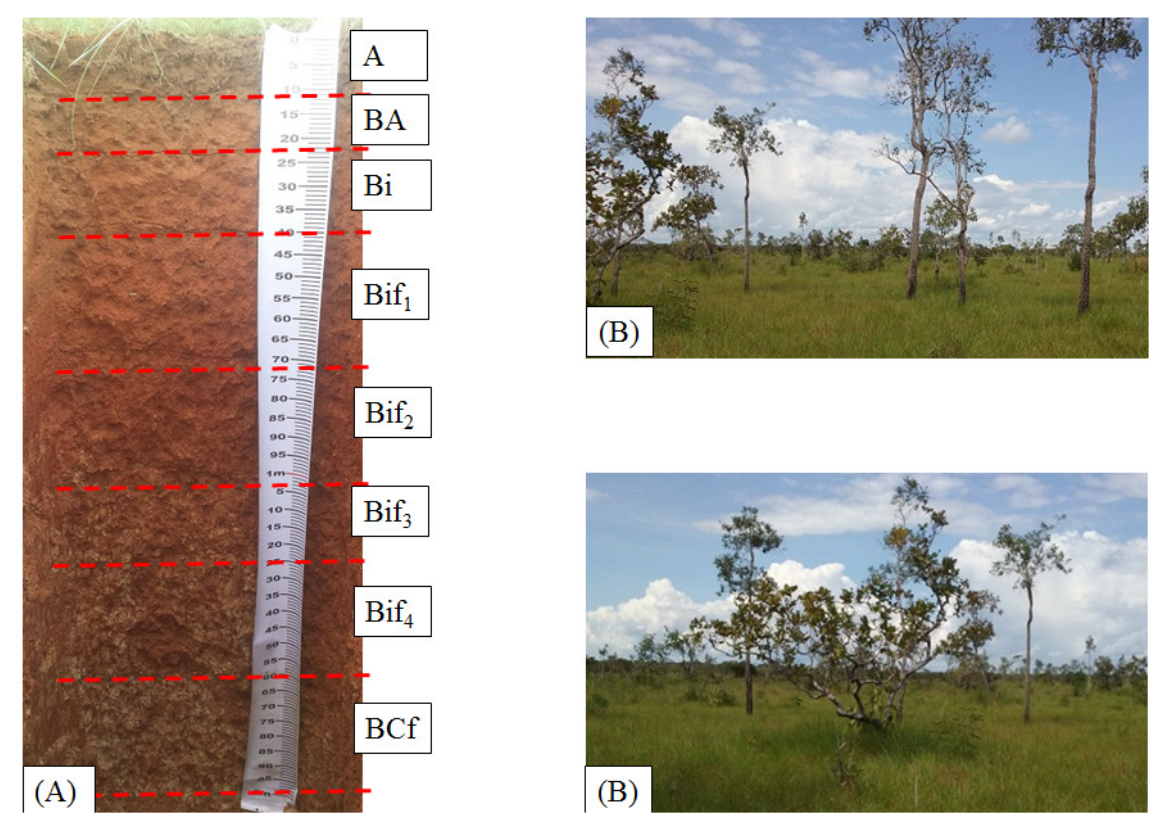

Figure 3. Typic Dystrudept profile (P2) in dirty field area in the Humaitá region, AM. (A) = soil profile and (B) = study environment. 

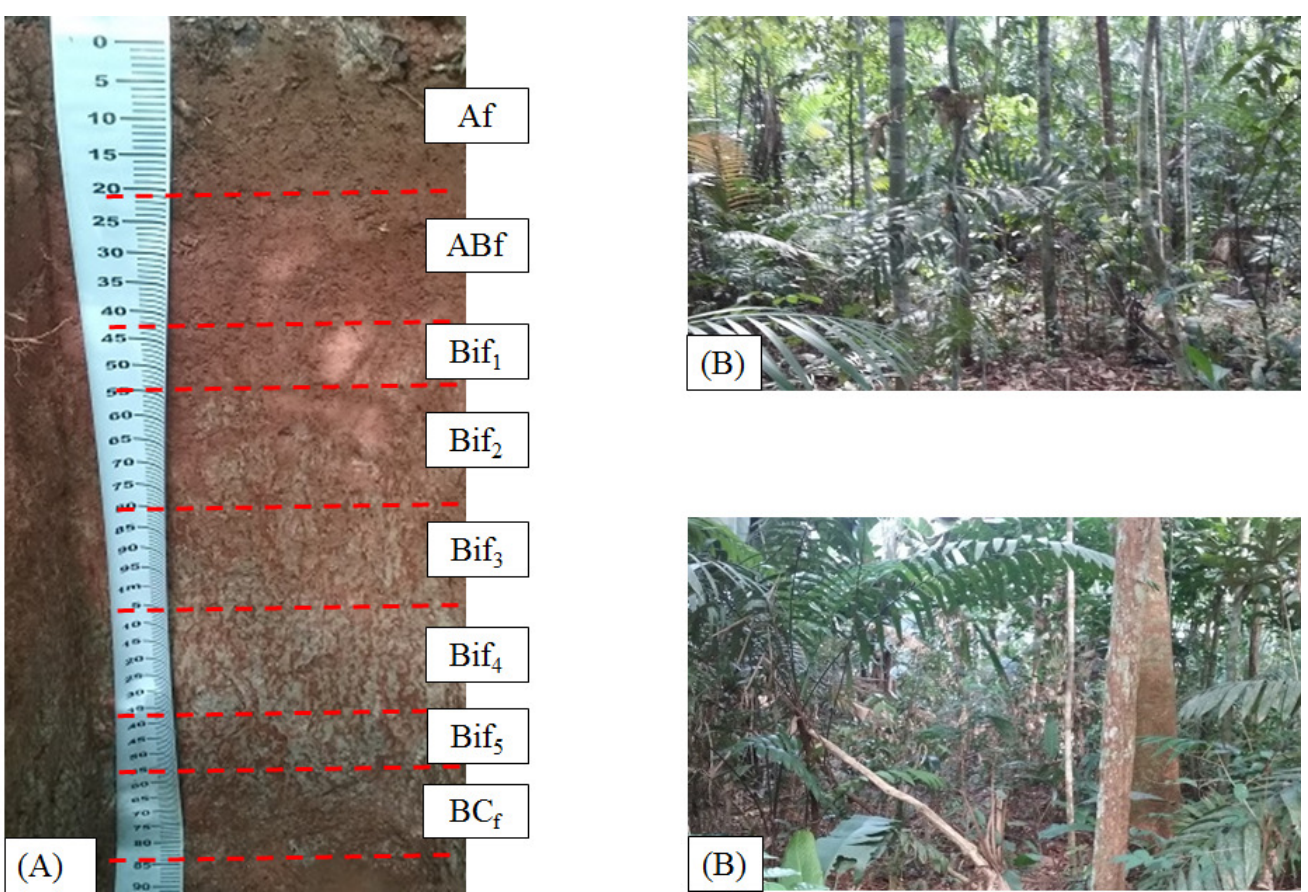

Figure 4. Typic Dystrudept profile (P3) in a forest area in the Humaitá region, AM. (A) = soil profile and (B) = study environment.

\section{Physical Attributes}

The soils presented little coarse fractions larger than $2 \mathrm{~mm}$, not reaching $15 \%$ in any of the soils (Table 2). The clay fraction was dominant for $\mathrm{P} 1$, presenting small increase in the last horizons. Rosolen \& Herpin (2008), affirm that topographic depressions in the landscape, favor the deposition of finer sediments.

For P2 and P3, the silt fraction was dominant in almost all horizons, except for the P2 $\mathrm{Bif}_{2}, \mathrm{Bif}_{4}$ and $\mathrm{BCf}$ horizons, which showed clay dominance, a fact justified by the presence of "clay pockets" in these horizons identified in the description and profile collection. The silt dominance in these profiles can be explained by the soil source material and the alluvial nature of the sediments that constitute the source material (Brazil, 1978). The silt fraction is considered to be indicative of the soil weathering degree or its potential to contain easily weathered primary minerals, that is, of its nutrient reserve (RESENDE et al., 1999).

The S/A ratio presented high values for the superficial horizons, between 2.23 and 1.28 for $\mathrm{P} 2$ and $\mathrm{P} 3$, respectively, while for the subsurface horizons the values decrease in depth reaching up to 0.31 . For the $\mathrm{P} 1$, the S/A ratio, presented for the superficial horizons values between 1.00 and 0.79 , having an increment in depth, but again decreasing at the end of the profile. Campos et al. (2012), studying soils toposequence in the natural-forest transition in the Humaitá region, found results very similar to the behavior of the S/A ratio for the same pedoenvironments. In relation to the bulk density, in all the studied profiles the lowest values are for the topsoil horizons, close to $1 \mathrm{Mg} \mathrm{m}^{-3}$, and for the subsurface horizons ranged from 1.11 and $1.60 \mathrm{Mg}$ $\mathrm{m}^{-3}$, presenting an increase in depth. For Martins et al. (2006), the lowest bulk density values in the topsoil horizons in relation to the subsurface, are due to the higher organic matter content. In relation to the higher bulk density values observed in the subsurface layers for the three profiles, these are not compaction indications, since they are natural environments, but possible soil densification factors, since, clay contents tend to increase in depth, thus leading to clay eluviation process corroborating with Martins et al. (2006); Campos et al. (2012) and Campos et al. (2013b) in natural environments in the Southern Amazonas.

The total porosity presented values above $50 \%$ for the surface horizons for all profiles, thus showing an inverse relationship with bulk density, that is, as the pores reduction with a $50 \mu \mathrm{m}$ lower limit and greater than $300 \mu \mathrm{m}$ occurs, due to pores clogging by clay fractions, the tendency is that there is a significant decrease in porosity, this being due to the very high clay levels and silt in the subsurface (Andrade et al., 2009). 
Table 2. Soil physical attributes for clean field, dirty field and forest areas in the Humaitá region, AM.

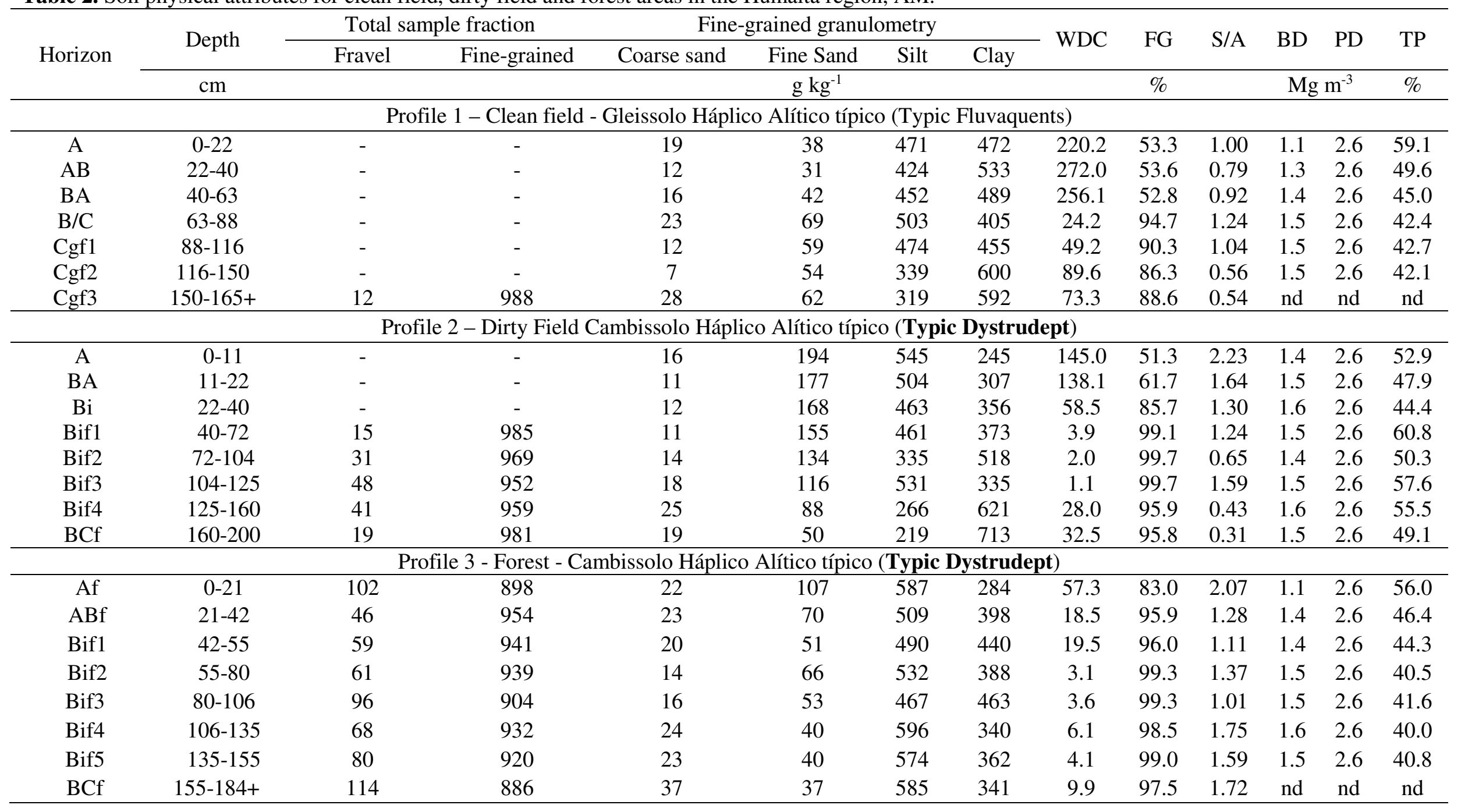




\section{Chemical attributes}

The soils natural fertility under forest and native field is considered very low (Table 3), Schubart et al. (1984) explain that soils under tropical forest present low nutrient due to the cycling conditioned by the fast-organic matter decomposition, causing the nutrients to concentrate in the biomass and not in the soil, constituting a nutrient conservation mechanism, maintaining the exuberance of the Amazon rainforest. In soils under field, their natural fertility low rates have been exhaustively recorded in the literature (BRAZIL, 1978, CARVALHO, 1986, CAMPOS et al., 2009, CAMPOS et al., 2011).

The $\mathrm{pH}$ in water values presented variations between 4.1 and 5.42 and the $\mathrm{pH}$ in $\mathrm{KCl}$ between 3.5 and 5.42. For all horizons the $\mathrm{pH}$ in $\mathrm{KCl}$ values were lower than $\mathrm{pH}$ in water values, establishing a negative $\Delta \mathrm{pH}$, evidencing the net negative charges predominance, showing that in these soils the cation exchange capacity (CEC) exceeds the anionic exchange ability under natural $\mathrm{pH}$ conditions (OLIVEIRA et al., 2003, FERNANDES et al., 2008). The highest $\Delta \mathrm{pH}$ negative values are for the Forest, then the dirty field and the clean field, unlike Campos et al. (2012), where the highest $\Delta \mathrm{pH}$ negative values were for the low vegetation field areas.

The organic carbon (OC) contents were higher in the topsoil horizons when compared to the subsurface horizons in all the profiles, this can be justified by the organic matter incorporation by vegetation and topography and hydromorphic influence (SANTOS et al., 2012). The P1 horizon was the one that obtained the highest OC value (31.2 $\mathrm{g} \mathrm{kg}^{-1}$ ), this occurs as P1 is the area with steeper slope in relation to the three profiles studied, so there is organic material accumulation, carried by water, observed by Campos et al. (2012), studying a toposequence for Field/Forest transition in the "Puciari fields region".

It is observed that the highest CEC value, for $\mathrm{P} 1 \mathrm{~A}$ horizon, is where the highest $\mathrm{OC}$ value is also found, together with a high clay percentage $(47.2 \%)$. The CEC decreases in depth, with a small increase again as the increase in clay content occurs. As the clay and soil organic matter increase, either in surface or subsurface, the CEC tends to increase, much due to these fractions colloids importance that work in the soil negative charges maintenance (KWEON et al., 2013). These results obtained for
CEC in all the environments, evidence and confirm that Amazonian soils the CEC is organic matter dependent (ROCHA; CERRI, 1994).

For base saturation $(\mathrm{V})$, it was verified that all the profiles studied, the $\mathrm{V}$ was below $10 \%$, evidencing the soils source material low fertility, these values confer the dystrophic character frequently found in literature studying soils in Amazônia region. (MARTINS et al., 2006, CAMPOS et al., 2012, SANTOS et al., 2012).

The $\mathrm{Al}^{3+}, \mathrm{H}+\mathrm{Al}$ and aluminum saturation values were higher for $\mathrm{P} 1$, corroborating with Santos et al. (2012) and disagreeing with Martins et al. (2006), that studying the native Humaitá fields, found the highest $\mathrm{Al}^{3+}, \mathrm{H}+\mathrm{Al}$ and aluminum saturation values in the forest environment, however, the lowest values found for the dirty field (high) corroborate with the authors mentioned above. Vidal-Torrado et al. (1999) and Campos et al. (2011) associate to the flat landform (greater water infiltration), favoring the exchangeable bases leaching increase in the soil profile, conditioning the lowland soils with respective increases in the variables that indicate the soils acidity. For the forest environment, such results can be equated with the oligotrophic theory reported by Alvim (1954) and Goodland (1971), who consider the aluminum toxic presence as an ecological factor of great effect on the vegetation occurrence in "Cerrados" fields and forests.

The available phosphorus levels presented similar behavior in all the studied environments, with an average value of $0.31 \mathrm{mg} \mathrm{kg}^{-1}$, decreasing in depth. Phosphorus remains stable in depth, due to the low mobility of its compounds (SILVA et al., 2006).

The total silicon, iron and aluminum oxides contents $\left(\mathrm{SiO}_{2}, \mathrm{Al}_{2} \mathrm{O}_{3}\right.$ and $\left.\mathrm{Fe}_{2} \mathrm{O}_{3}\right)$ are presented in Table 4, which showed a decrease in depth for all profiles studied. The lower $\mathrm{SiO}_{2}$ contents were found in the forest environment, evidencing a more weathered environment in relation to the others. For the aluminum oxide $\left(\mathrm{Al}_{2} \mathrm{O}_{3}\right)$ contents, it was verified that the clean field environment presented higher values in relation to the dirty field and forest environments. In environments that are constantly saturated with water, there is the mobilization, redistribution and export of iron, silica, aluminum and other chemical elements (ROSOLEN; HERPIN, 2008). 
Table 3. Soil chemical attributes in clean field, dirty field and forest areas in the Humaitá region, AM.

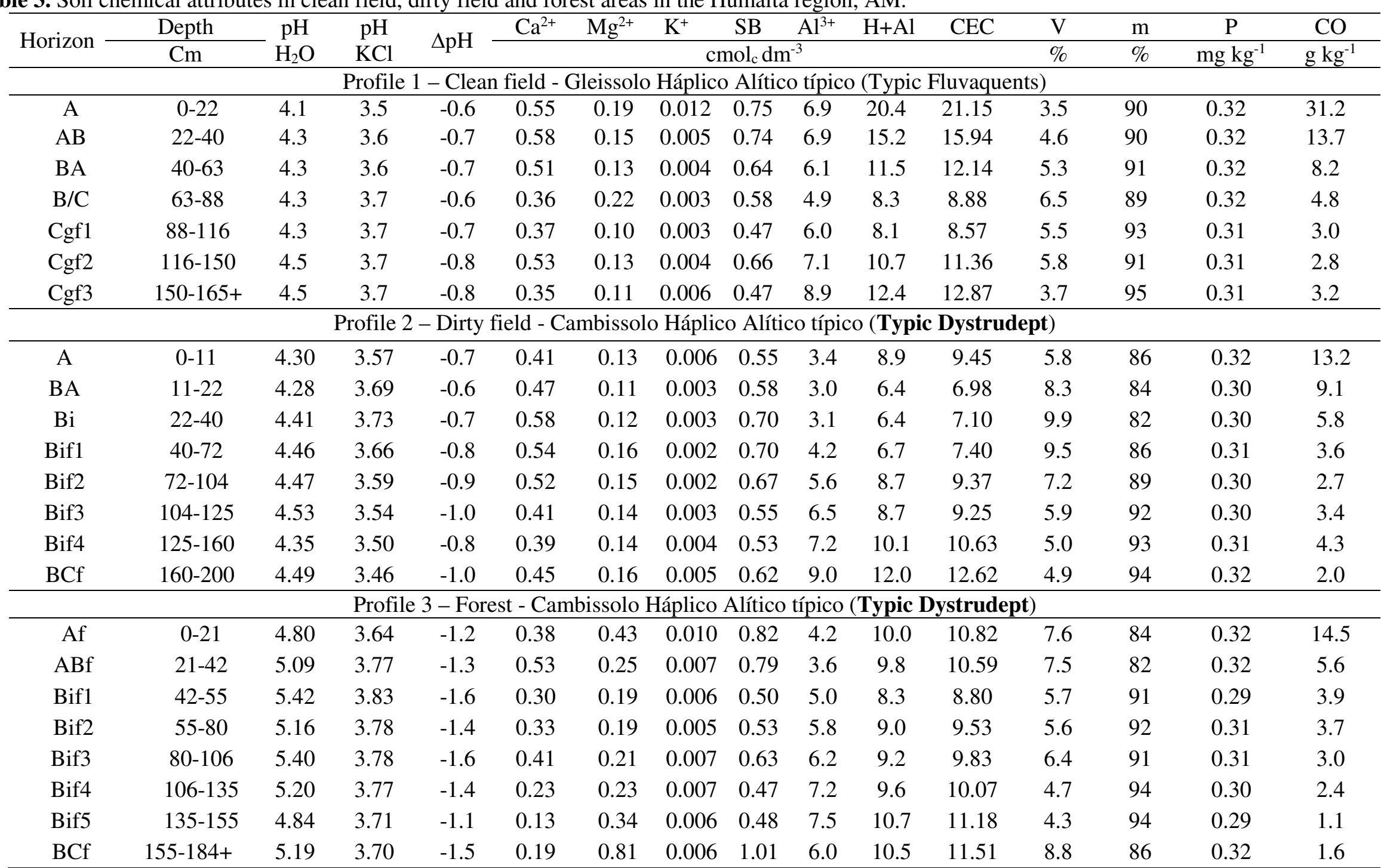


In relation to the $\mathrm{Fe}_{2} \mathrm{O}_{3}$ contents, different values were observed to the studied profiles, with less expressive results in the forest environment compared to the other environments. The greater hydromorphic conditions can cause reduction of the iron and clay oxides contents by ferrolysis. In addition, according to Schaefer \& Dalrymple (1996) the high organic matter levels and the source material low fertility can contribute to these results. Total $\mathrm{Fe}_{2} \mathrm{O}_{3}$ contents were lower than $\mathrm{Al}_{2} \mathrm{O}_{3}$ contents (Table 4), following the oxides extracted by sulfur digestion tendency. A comparison between the extraction methods (total and sulfuric digestion) reveals higher contents when the digestion was total, although in some horizons the contents are very close, indicating that these oxides are found in great part in soils clay fraction, corroborating with Pereira et al. (2010) studying Oxisols and Cambisols genesis.

The $\mathrm{Ki}$ and $\mathrm{Kr}$ molecular relationships were low, demonstrating the advanced soils weathering stage, despite that, it was verified values very heterogeneous between the profiles studied. According to Campos et al. (2012), these results are mainly due to the landform variation, which drives drainage and groundwater level, allowing the oxidation/reduction of $\mathrm{Fe}, \mathrm{Si}$ and $\mathrm{Al}$ components and subsequent redistribution along the soil profile.

Table 4. Sulfuric attack oxides levels $\left(\mathrm{SiO}_{2}, \mathrm{Fe}_{2} \mathrm{O}_{3}, \mathrm{Al}_{2} \mathrm{O}_{3}\right)$ and relations between them in clean field, dirty field and forest areas at Humaitá region $\mathrm{AM}$

\begin{tabular}{|c|c|c|c|c|c|}
\hline Horizons & $\mathrm{SiO}_{2}$ & $\mathrm{Fe}_{2} \mathrm{O}_{3}$ & $\mathrm{Al}_{2} \mathrm{O}_{3}$ & $\mathrm{Ki}$ & $\mathrm{Kr}$ \\
\hline \multicolumn{6}{|c|}{ dag $\mathrm{kg}^{-1}$} \\
\hline \multicolumn{6}{|c|}{ Profile 1 - Clean field - Gleissolo Háplico Alítico típico (Typic Fluvaquents) } \\
\hline A & 0,83 & 1,06 & 1,26 & 1,12 & 0,73 \\
\hline BA & 0,71 & 1,17 & 1,46 & 0,83 & 0,55 \\
\hline Cgf1 & 1,18 & 1,19 & 1,60 & 1,25 & 0,85 \\
\hline \multicolumn{6}{|c|}{ Profile 2 - Dirty field - Cambissolo Háplico Alítico típico (Typic Dystrudept) } \\
\hline A & 0,57 & 1,07 & 1,06 & 0,91 & 0,56 \\
\hline BA & 0,76 & 1,50 & 1,44 & 0,90 & 0,54 \\
\hline Bif3 & 1,08 & 2,29 & 1,59 & 1,15 & 0,60 \\
\hline \multicolumn{6}{|c|}{ Profile 3 - Forest - Cambissolo Háplico Alítico típico (Typic Dystrudept) } \\
\hline Af & 0,53 & 0,84 & 0,76 & 1,19 & 0,70 \\
\hline BA & 0,68 & 1,01 & 1,21 & 0,96 & 0,62 \\
\hline $\mathrm{Bif}_{4}$ & 0,83 & 1,65 & 1,64 & 0,86 & 0,52 \\
\hline
\end{tabular}

Ki: $\% \mathrm{SiO}_{2} \times 1,7 / \% \mathrm{Al}_{2} \mathrm{O}_{3} ; \mathrm{Kr}_{2} \% \mathrm{SiO}_{2} \times 1,7 /\left(\% \mathrm{Al}_{2} \mathrm{O}_{3}+\% \mathrm{Fe}_{2} \mathrm{O}_{3} \times 0,64\right)$

\section{Principal Component Analysis (PCA)}

In order to evaluate the physical, chemical and mineralogical attributes interaction between profiles, Principal Component Analysis (PCA) was applied (Figure 5). The PCA confirmed the results presented for the profile characterization (Tables 2, 3 and 4). It was observed in the surface and subsurface horizons that the profiles were divided in three groups, that is, there was no similarity association among the studied environments, thus indicating the total independence and differentiation between the physical, chemical and mineralogical attributes studied.

The first group was formed by P1 in the surface horizons, indicating the strong relationship with variables that are related to soil acidity, such as
$\mathrm{Al}^{3+}$ content, aluminum saturation $(\mathrm{m})$, potential acidity $(\mathrm{H}+\mathrm{Al})$, indicating soils under native fields present low natural fertility due to the environment formation conditions, and corroborating with Campos et al. (2011) who also found this pattern in natural environments in the " Puciari Fields" region. The second group characterized by $\mathrm{P} 2$ shows the direct relationship with bulk density, $\mathrm{Fe}_{2} \mathrm{O}_{3}, \mathrm{~V}, \mathrm{pH}$ $(\mathrm{KCl})$ and sand. The higher bulk density ratio in this profile does not indicate compaction pattern, but rather, that this profile is more subject to the clay eluviation processes, leading to pore clogging and thickened layers formation, Martins et al. (2006) found denser layers in low field areas, much due to sediment transport to these sites. 

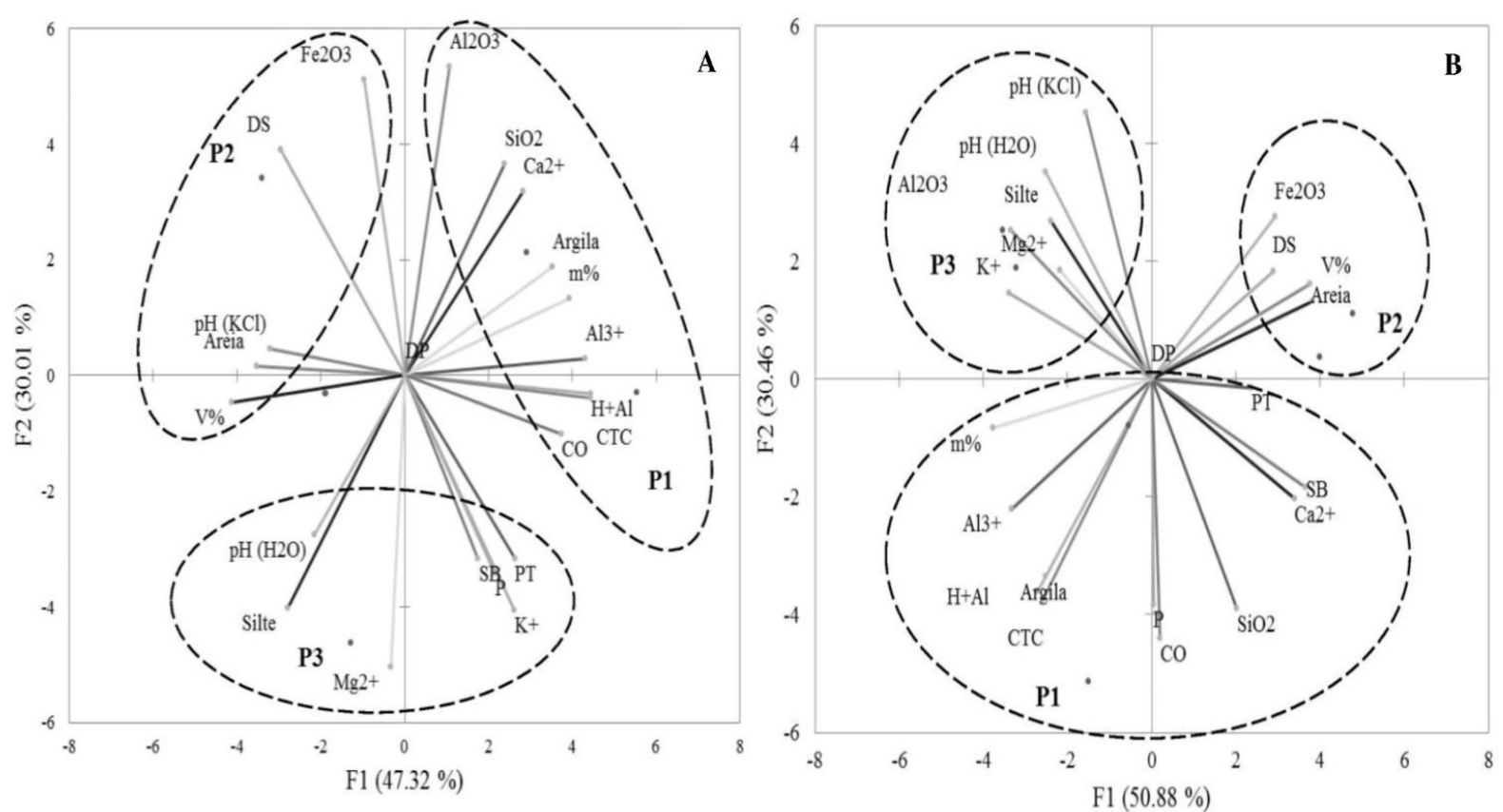

Figure 5. Principal component analysis for the profiles surface (a) and subsurface (b) horizons.

The third group formation characterized by $\mathrm{P} 3$, indicates the soil fertility variables predominance such as $\mathrm{Mg}^{2+}, \mathrm{K}^{+}, \mathrm{SB}$ and $\mathrm{P}$, exposing the chemical environments condition under native forest areas. This natural condition expresses the organic matter input that is deposited in this environment. Gomes et al. (2004) and Fernandes et al. (2016) found this same distribution pattern in an area under forest and "Cerrados" environments, indicating the great nutrient cycling capacity and favoring natural fertility maintenance in superficial horizons.

For subsurface horizons, the variable distribution behavior was similar to the surface horizons, with the exception of $\mathrm{pH}(\mathrm{KCl})$ grouping with P3 in the subsurface horizons.

\section{CONCLUSIONS}

The forest, dirty field and clean field environments presented different soil classes, Inceptisols for the first two and Gleissolo for the third, justified by the topography conditions and soil moisture in which the soils are conditioned, intensifying the formation processes.

The clean field lower profile position, classified as Entisols favored the gleying horizon formation, due to the water table proximity, showing a great variation in its level.

The main components analysis has a great importance to understand soil properties and to group soils with similar characteristics, making it possible to identify the variation pattern for Amazonas region soil classes.

\section{ACKNOWLEDGEMENTS}

The authors argue the Federal University of Amazonas (UFAM) and the Foundation for Research Support of the State of Amazonas (FAPEAM), for the financial contribution destined to research and all structure in conducting the experimental analyzes.

RESUMO: As características do solo e da vegetação da região sul do Amazonas incluem solos altamente intemperizados, alto teor de alumínio e algumas condições hidromórficas, sendo sua vegetação composta por pastos, pequenas árvores isoladas e galerias florestais ao longo dos cursos d'água. Desta forma, este trabalho tem como objetivo caracterizar e classificar o solo em áreas de campo limpo, campo sujo e floresta na região de Humaitá AM. As valas foram abertas no campo limpo, no campo sujo e nos ambientes florestais, os perfis dos solos foram caracterizados morfologicamente e as amostras foram coletadas de seus horizontes. Análises físicas de textura, argila dispersa em água, floculação, densidade do solo, densidade de partículas e porosidade foram realizadas. As análises químicas incluíram $\mathrm{pH}$ e $\mathrm{KCl}$ em água; $\mathrm{Ca}, \mathrm{Mg}, \mathrm{K}, \mathrm{Al}$ e; $\mathrm{P}$ disponível; H + Al e C orgânico; Ataque sulfúrico de SiO2, Al2O3 e Fe2O3. Os solos foram classificados de 
acordo com critérios estabelecidos pelo Sistema Brasileiro de Classificação de Solos e Taxonomia de Solos. A mata, o campo sujo (alto) e o campo limpo (baixo) apresentaram diferentes tipos de solo, distritos típicos para os dois primeiros ambientes e fluídicos típicos para o último. Técnicas multivariadas expressaram as relações de similaridade que se apresentam entre os diferentes ambientes estudados, caracterizando, que são de grande importância na relação paisagem-solo.

PALAVRAS-CHAVE: Solo amazônico. Gênese do solo. Atributos do solo. Classificação do solo.

\section{REFERENCES}

ALVIM, P. T. Teoria sobre a formação dos campos cerrados. Revista Brasileira de Geografia, v. 16, n. 4, p. 496-498, 1954.

ANDRADE, R. S.; STONE, L. F.; SILVEIRA, P. M. Culturas de cobertura e qualidade física de um Latossolo em plantio direto. Revista Brasileira de Engenharia Agrícola e Ambiental, v. 13, n. 4, p. 411-418, 2009. http://dx.doi.org/10.1590/S1415-43662009000400007.

BRASIL, Ministério das Minas e Energia. Projeto Radam Brasil, folha SB. 20, Purus. Rio de Janeiro: 1978.

BRAUN, E. H. G.; RAMOS, J. R. A. Estudo agroecológico dos campos Puciari-Humaitá Estado do Amazonas e Território Federal de Rondônia. Revista Brasileira de Geografia, v. 21, n. 2, p. 443-497, 1959.

CAMPOS, M. C. C.; RIBEIRO, M. R.; SOUZA JÚNIOR, V. S.; RIBEIRO FILHO, M. R.; ALMEIDA, M. C. Topossequência de solos na transição Campos Naturais-Floresta na região de Humaitá, Amazonas. Acta Amazônica, v. 42, n. 3, p. 387 - 398, 2012. http://dx.doi.org/10.1590/S0044-59672012000300011.

CAMPOS, M. C. C.; RIBEIRO, M. R.; SOUZA JÚNIOR, V. S.; RIBEIRO FILHO, M. R.; SOUZA, R. V. C. Relações solo-paisagem em uma topossequência sobre substrato granítico em Santo Antônio do Matupi,

Manicoré AM. Revista Brasileira Ciência do Solo, v. 35, n. 1, p. 13-23, 2011.

http://dx.doi.org/10.1590/S0100-06832011000100002.

CAMPOS, M. C. C.; RIBEIRO, M. R.; SOUZA JÚNIOR, V. S.; RIBEIRO FILHO, M. R.; SOUZA, R. V. C.; AQUINO, R. E.; OLIVEIRA, I. A. Superfícies geomórficas e atributos do solo em uma topossequência de transição várzea-terra firme. Bioscience Journal, v. 29, n. 1, p. 132-142, 2013 b.

CAMPOS, M. C. C.; MARQUES JUNIOR, J.; MARTINS, M. V.; SOUZA, Z. M.; BORGES, R. C. T. Geomorphic surface and estimation of soil erosion on a sandstone-basalt substractum of a toposequence in Jardinópolis São Paulo. Revista de Ciências Agrárias, v. 56, n. 3, p. 227-234, 2013 a.

http://dx.doi.org/10.4322/rca.2013.033.

CAMPOS, M. C. C.; MARQUES JÚNIOR, J.; PEREIRA, G. T.; MONTANARI, R.; CAMARGO, L. A. Relações solo-paisagem em uma litosseqüência arenito-basalto na região de Pereira Barreto, SP. Revista Brasileira Ciência do Solo, v. 31, n. 3, p. 519-529, 2007. http://dx.doi.org/10.1590/S010006832007000300012.

CAMPOS, M. C. C. Pedogeomorfologia aplicada a ambientes amazônicos do médio Rio Madeira. 2009. 242 f. Tese Doutorado em Ciência do Solo - Universidade Federal Rural de Pernambuco, Recife, 2009.

CARVALHO, A.M. Caracterização física, química e mineralógica dos solos do município de HumaitáAM. Livre Docência. 166 f. Universidade do Estado de São Paulo, Botucatu, 1986.

EMPRESA BRASILEIRA DE PESQUISA AGROPECUÁRIA - EMBRAPA. Manual de métodos de análise de solos. $2^{\mathrm{a}}$ ed. Rio de Janeiro: Embrapa Solos; 2011. 230p. 
EMPRESA BRASILEIRA DE PESQUISA AGROPECUÁRIA - EMBRAPA. Manual de métodos de análise de solo. $2^{\mathrm{a}}$ ed. Rio de Janeiro: 1979. 212p.

EMPRESA BRASILEIRA DE PESQUISA AGROPECUÁRIA - Embrapa. Sistema brasileiro de

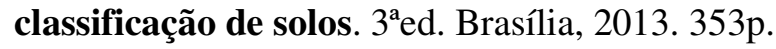

FERNANDES, J. D.; CHAVES, L. H. G.; OLIVEIRA, F. H. T.; FARIAS, D. R. Ponto de efeito salino nulo e cargas elétricas de solos do estado da Paraíba. Revista Caatinga, v. 21, n. 2, p. 147-155, 2008.

FERNANDES, K. L.; RIBON, A. A.; MARQ UES JÚNIOR, J.; BAHIA, A. S. R. S.; TAVARES FILHO, J. Characterization, classification and analysis of the main properties of the Southwestern Goias soil. Semina: Ciências Agrárias, v. 37, n. 3, p. 1135-1154, 2016.

FLINT, A. L.; FLINT, L. E. Particle density. In: Dane JH, Topp GC. editors. Methods of soil analysis. Physical methods. Madison: American Society of Agronomy; Soil Science Society of America; 2002. Pt 4, 229-240.

FREITAS, H. A.; PESSENDA, L. C. R.; ARAVENA, R.; GOUVEIA, S. E. M.; RIBEIRO, A. S.; BOULET, R. Florestas x Savanas no passado na Amazônia. Ciência Hoje, v. 32, n. 189, p. 40-46, 2002.

GOMES, J. B. V.; CURI, N.; MOTTA, P. E. F.; KER, J. C.; MARQUES, J. J. G. S. M.; SCHULZE, D. G. Análise de componentes principais de atributos físicos, químicos e mineralógicos de solos do bioma Cerrado. Revista Brasileira de Ciência do Solo, v. 28, n. 1, p. 137-153, 2004. http://dx.doi.org/10.1590/S010006832004000100014

GOODLAND, R. Oligotrofismo e alumínio no cerrado. In $3^{\circ}$ Simpósio sobre o Cerrado; 1971; São Paulo. Anais. São Paulo: USP; 1971. 44-60.

GUIMARÃES, S. T.; LIMA, H. N.; TEIXEIRA, W. G.; NEVES JUNIOR, A. F.; SILVA, F. W. R.; MACEDO, R. S.; SOUZA, K. W. Caracterização e classificação de Gleissolos da várzea do rio Solimões Manacapuru e Iranduba, Amazonas, Brasil. Revista Brasileira de Ciência do Solo, v. 37, n. 2, p. 317-26, 2013. http://dx.doi.org/10.1590/S0100-06832013000200003.

KWEON, G.; LUND, E., MAXTON, C. Soil organic matter and cation-exchange capacity sensing with on-thego electrical conductivity and optical sensors. Geoderma, v. 199, n. 1, p. 80-89, 2013.

https://doi.org/10.1016/j.geoderma.2012.11.001.

MARTINS, G. C.; FERREIRA, M. M.; CURI, N.; VITORINO, A. C. T.; SILVA, M. L. N. Campos nativos e matas adjacentes da região de Humaitá AM: atributos diferencias dos solos. Ciência Agrotecnologia, v. 30, n. 2, p. 221-227, 2006. http://dx.doi.org/10.1590/S1413-70542006000200005.

MEIRELES, H. T.; MARQUES JÚNIOR, J.; CAMPOS, M. C. C.; PEREIRA, G. T. Relações solo-paisagem em topossequência de origem basáltica. Pesquisa Agropecuária Tropical, v. 42, n. 2, p. 129-136, 2012. http://dx.doi.org/10.1590/S1983-40632012000200001

MINASNY, B.; MCBRATNEY, A. B. Mechanistic soil-landscape modelling as an approach to developing pedogenetic classifications. Geoderma, v. 133, n. 1, p. 138-149, 2006.

https://doi.org/10.1016/j.geoderma.2006.03.042

OLIVEIRA, L. B.; RIBEIRO, M. R.; FERRAZ, F. B.; JACOMINE, P. K. T. Classificação de solo Planossólicos do sertão do Araripe PE. Revista Brasileira de Ciência do Solo, v. 27, n. 4, p. 685-693, 2003. http://dx.doi.org/10.1590/S0100-06832003000400013.

PENNOCK, D. J.; VELDKAMP, A. Advances in landscape-scale soil research. Geoderma, v. 133, n. 1-2, p. 15, 2006. https://doi.org/10.1016/j.geoderma.2006.03.032. 
PEREIRA, T. T. C.; KER, J. C.; SHAEFER, C. E. G. R.; BARROS, N. F.; NEVES, J. C. L.; ALMEIDA, C. C. Gênese de Latossolos e Cambissolos desenvolvidos de rochas pelíticas do grupo bambuí - Minas Gerais. Revista Brasileira de Ciência do Solo, v. 34, n. 4, p. 1283-1295, 2010. http://dx.doi.org/10.1590/S010006832010000400026.

RANZI, A. A. Paleofauna da Amazônia indica áreas de pastagem com pouca cobertura vegetal. Ciência Hoje, v. 16, n. 45 , p. $48-51,1993$.

RESENDE, M.; CURI, N.; REZENDE, S. B.; CORREAA, G. F. Pedologia: base para distinção de ambientes. Viçosa: NEPUT; 1999. 367p.

ROCHA, G. C.; CERRI, C. C. Características e organização de uma topossequência de solos sobre rocha básica na Amazônia Brasileira. Revista Brasileira de Ciência do Solo, v. 18, n. 1, p. 117-123, 1994.

ROSOLEN, V.; HERPIN, U. Expansão dos solos hidromórficos e mudanças na paisagem: um estudo de caso na região sudeste da Amazônia brasileira. Acta Amazônica, v. 38, n. 3, p. 483-490, 2008.

SANTOS, L. A. C.; CAMPOS, M. C. C.; COSTA, H. S.; PEREIRA, A. R. Caracterização de solos em uma topossequência sob terraços aluviais na região do médio rio Madeira AM. Ambiência, v. 8, n. 3, p. 319-331, 2012.

SANTOS, R. D.; LEMOS, R. C.; SANTOS, H. G.; KER, J. C.; ANJOS, L. H. C.; SHIMIZU, S. H. Manual de descrição e coleta de solo no campo. $6^{a}$ ed. rev ampl. Viçosa, MG: Sociedade Brasileira de Ciência de Solo; 2013. 100p.

SCHAEFER, C. E. R. G.; DALRYMPLE, J. B. Pedogenesis and relict properties of soil with columnar structure from Roraima, North Amazonia. Geoderma, v. 71, n. 1-2, p. 1-17, 1996.

https://doi.org/10.1016/0016-7061(95)00073-9.

SCHUBART, H. O. R.; FRANKEN, W.; LUIZÃO, F. J. Uma floresta sobre solos pobres. Ciência Hoje, v. 2, n. 1, p. 26-32, 1984.

SILVA, G. R.; SILVA JUNIOR, M. L.; MELO, V. S. Efeitos de diferentes usos da terra sobre as características químicas de um Latossolo amarelo do estado do Pará. Acta Amazônica, v. 36, n. 2, p. 151-158, 2006. http://dx.doi.org/10.1590/S0044-59672006000200004.

SOIL SURVEY STAFF. Keys to Soil Taxonomy. 12th Ed. USDA Natural Resources Conservation Service, Washington, DC. 2014

STATSOFT. Statistica 7.0. Tulsa: StatSoft; 2004.

VIDAL-TORRADO, P.; LEPSCH, I. F.; CASTRO, S. S.; COOPER, C. Pedogênese em uma sequência Latossolo Podzólico na borda de um platô na depressão periférica paulista. Revista Brasileira de Ciência do Solo, v. 23, n. 4, p. 909-921, 1999. http://dx.doi.org/10.1590/S0100-06831999000400018.

YEOMANS, J. C.; BREMNER, J. M. A rapid and precise method for routine determination of organic carbon in soil. Soil Science Plant Analysis, v. 19, n. 13, p. 1467-1476, 1988.

https://doi.org/10.1080/00103628809368027 